\title{
REVITALISASI PENDIDIKAN KARAKTER MELALUI ISLAMISASI KAMPUS DI UNIVERSITAS MUHAMMADIYAH SUKABUMI
}

\author{
Andri Moewashi Idharoel Haq', Muhammad Thariq Aziz ${ }^{2}$ \\ andrimoewashi@gmail.com \\ ${ }^{1}$ Universitas Muhammadiyah Sukabumi
}

\begin{abstract}
Campus Islamization has been held at Muhammadiyah University Sukabumi since 2014 but its effectiveness has not been measured especially to revitalize student character education. This research is a descriptive study with a quantitative approach. The instruments used included observation sheets for student activities in the classroom and campus environment. The results of the research show that the highest character is discipline (93.3\%) and the lowest is the national spirit (60\%) and the highest character is hard work (84\%) and the lowest is fond of reading (61\%). So it can be concluded that the results of the study show character that is expected to become complete information about the implementation of Islamization on campus as a form of efforts to revitalize character education especially at the University of Muhammadiyah Sukabumi.
\end{abstract}

Keywords: Campus Islamization, Revitalization, Character Education

\begin{abstract}
Abstrak
Islamisasi kampus telah dilaksanakan di Universitas Muhammadiyah Sukabumi sejak tahun 2014 namun belum diukur efektifitasnya terutama untuk merevitalisasi pendidikan karakter mahasiswa. Penelitian ini merupakan penelitian deskriptif dengan pendekatan kuantitatif. Instrumen yang digunakan antara lain lembar observasi aktifitas mahasiswa di lingkungan kelas dan kampus. Hasil pelaksanaan penelitian menunjukkan bahwa karakter paling tinggi yakni disiplin (93.3\%) dan yang paling rendah adalah semangat kebangsaan (60\%) serta karakter paling tinggi yakni kerja keras $(84 \%)$ dan yang paling rendah adalah gemar membaca $(61 \%)$. Jadi dapat disimpulkan bahwa hasil penelitian menunjukkan karakter yang diharapkan menjadi informasi yang utuh mengenai pelaksanaan islamisasi di kampus sebagai bentuk upaya merevitalisasi pendidikan karakter khususnya di Universitas Muhammadiyah Sukabumi.
\end{abstract}

Kata kunci: Islamisasi Kampus, Revitalisasi, Pendidikan Karakter

\section{PENDAHULUAN}

Pendidikan karakter saat ini sedang direvitalisasi atau diberdayakan terutama di Kementrian Pendidikan. Di Indonesia revitalisasi pendidikan karakter diangkat pada tahun 2010 selanjutnya disosialisasikan untuk dapat diimplementasikan di semua jenjang Pendidikan. Pendidikan Karakter direvitalisasi atau digalakkan kembali dalam upaya mengatasi problem moral yang saat ini semakin dianggap kronis bagi bangsa Indonesia. Sebut saja penculikan, pembunuhan, perampokan, pencurian, pelecehan seksual, perusakan alam, menjadi berita yang kita konsumsi sehari-hari dalam media 
cetak maupun elektronik. Semua itu menjadi alasan mengapa pendidikan karakter penting diterapkan dalam dunia pendidikan (Johansyah, 2011).

Menurut Darmiyati materi pendidikan karakter dapat dikelompokkan ke dalam tiga hal nilai moral atau nilai akhlak yaitu pertama, akhlak terhadap Tuhan yang Maha Esa, mengenal Tuhan sebagai pencipta dan sifat-sifatNya, dan meminta tolong kepadaNya. Kedua, akhlak terhadap diri sendiri, orang tua, orang yang lebih tua, teman sebaya, dan orang yang lebih muda. Ketiga, akhlak terhadap lingkungan (alam, baik flora maupun fauna dan sosial masyarakat) (Kristiawan, 2015; Zuchdi, 2010).

Kaitannya dengan pendidikan karakter, dalam islam terdapat tiga nilai utama yaitu akhlak, adab, dan keteladanan. Akhlak merujuk pada tugas dan tanggung jawab selain syariah dan ajaran islam secara umum, adab merujuk pada sikap yang dihubungkan dengan tingkah laku yang baik, dan keteladanan merujuk pada kualitas karakter yang ditampilan oleh seseorang muslim yang baik yang mengikuti keteladanan Nabi Muhammad SAW.

Berdasarkan konsep tersebut dapat difahami bahwa pendidikan karakter sangat berkaitan dengan pendidikan Islam. Jika diamati lebih lanjut bahwa pilar dalam pendidikan karakter menjadi indikator keberhasilan yang harus dicapai dalam pendidikan Islam (Majid \& Andayani, 2012). Artinya pendidikan karakter sangat mungkin dilatihkan dalam konteks pendidikan islami, dalam pemahaman, penghayatan dan pengamalan nilai-nilai islam dalam setiap kegiatan yang dilakukan oleh peserta didik, dalam penelitian ini adalah mahasiswa.

Kegiatan islamisasi kampus yang selama ini telah dilaksanakan di UMMI belum pernah diukur tingkat efektivitasnya terhadap revitalisasi pendidikan karakter secara menyeluruh dan mendalam sesuai dengan indikator yang ditentukan. Indikator karakter merujuk pada 18 indikator menurut Kemendiknas pada tahun 2011, antara lain, 1) Religius, 2) Jujur, 3) Toleransi, 4) Disiplin, 5) Kerja Keras, 6) Kreatif, 7) Mandiri, 8) Demokratis, 9) rasa ingin tahu, 10) Semangat kebangsaan, 11) Cinta tanah air, 12) Menghargai prestasi, 13) Komunikatif, 14) Cinta damai, 15) Gemar Membaca, 16) Peduli Lingkungan, 17) Peduli sosial, 18) Tanggung jawab (Hamid \& Sudira, 2013).

Berdasarkan hasil penelitian terdahulu, telah dilakukan beberapa penelitian tentang revitalisasi (Emmanuel, 2015; Hanrahmawan, 2010; Natasha, 2012; Sakdiyah, 2010; Sitorus, 2008; Sulianti, 2018), serta pendidikan karakter (Akhsania, 2018; Amri, 
2018; Azizah, Muslihudin, \& Suteja, 2013; Dalimunthe, 2015; Hasyim, 2015; Johansyah, 2011; Judiani, 2010; Kristiawan, 2015; Lalo, 2018; Munif, 2018; Muslich, 2018; Shobahiya \& Suseno, 2013; Sudrajat, 2011; Tohirin, 2016; Wahono, 2018; Zuchdi, 2010; Zulhijrah, 2015) di berbagai bidang dan beberapa penelitian membahas tentang revitalisasi pendidikan karakter (Iriany, 2014; Juanda, 2018; Kunaepi, 2013; Musanna, 2010; Yuliana, 2012). Namun, belum terdapat penelitian sebelumnya yang membahas tentang islamisasi kampus. Maka, tujuan penelitian untuk mengungkap islamisasi kampus yang dilaksanakan di lingkungan kelas dan kampus terhadap revitalisasi pendidikan karakter bagi mahasiswa di Universitas Muhammadiyah Sukabumi. Dengan rumusan masalahnya adalah sebagai berikut: "Bagaimanakah karakter yang ditampilkan mahasiswa melalui kegiatan islamisasi kampus di Universitas Muhammadiyah Sukabumi?.”

\section{METODE PENELITIAN}

Metode penelitian yang digunakan adalah metode deskriptif melalui pendekatan kuantitatif. Hal yang dideskripsikan dalam penelitian ini mencakup, pelaksanaan kegiatan islamisasi kampus yang dilaksanakan di kelas dan luar kelas (kampus) bagi mahasiswa UMMI, upaya revitalisasi pendidikan karakter yang dilatihkan dalam kegiatan islamisasi kampus di UMMI, serta kendala apa saja yang dihadapi dalam kegiatan islamisasi kampus terhadap revitalisasi pendidikan karakter. Populasi adalah seluruh mahasiswa dari 20 program studi dengan sampel sebanyak satu mata kuliah per program studi, dengan melibatkan 20 orang dosen yang mewakili setiap program studi. Waktu penelitian mulai bulan April-Juli 2018.

Instrumen yang digunakan untuk mengamati revitalisasi pendidikan karakter adalah lembar observasi di lingkungan kelas dan sekitar kampus sebagai data primer, serta lembar wawancara sebagai data sekunder. Wawancara dilakukan terhadap 5 orang dosen yang dipilih secara random. Analisis hasil wawancara dianalisis secara kualitatif untuk mendukung hasil penelitian yang disajikan dalam pembahasan, sementara analisis lembar observasi dilakukan dengan cara: 1) Mengelompokkan data yang terkumpul, 2) Mentabulasi data, 3) menghitung persentase tiap jawaban dengan teknik persentase sederhana:

$$
\% \mathrm{x}=\frac{\mathrm{\Sigma} \text { Cuplikan }}{\Sigma \text { Total maksimal }} \times 100 \%
$$




\section{HASIL PENELITIAN DAN PEMBAHASAN}

Pada bagian ini akan diuraikan hasil penelitian mengenai gambaran karakter mahasiswa yang dioptimalisasikan melalui islamisasi kampus di lingkungan kelas dan kampus secara keseluruhan. Rata-rata persentase karakter yang teramati di kampus per indikator dapat dilihat pada Grafik 1.1 di bawah ini:

\section{Grafik 1.1}

Rata-rata Persentase Karakter yang Ditampilkan Mahasiswa di Kampus Per Indikator

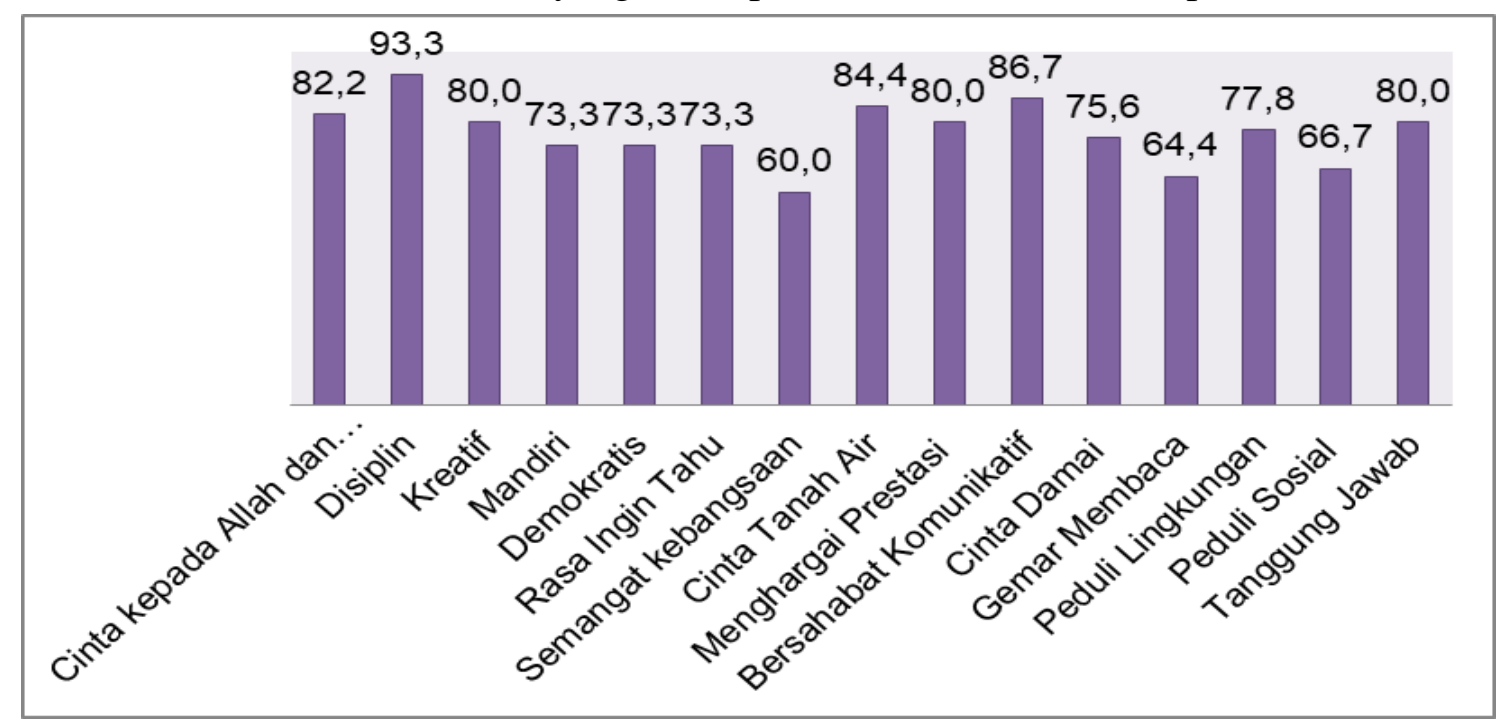

Grafik 1.1 Memperlihatkan rata-rata persentase karakter yang ditampilkan mahasiswa di kampus per indikator. Karakter paling tinggi yakni disiplin (93.3\%) dan yang paling rendah adalah semangat kebangsaan (60\%). Selain diamati di lingkungan kampus karakter juga diamati di lingkungan kelas, adapun data disajikan pada Grafik 1.2 di bawah ini: 


\section{Grafik 1.2}

Rata-Rata Persentase Karakter yang Ditampilkan Mahasiswa di Kelas Per Indikator

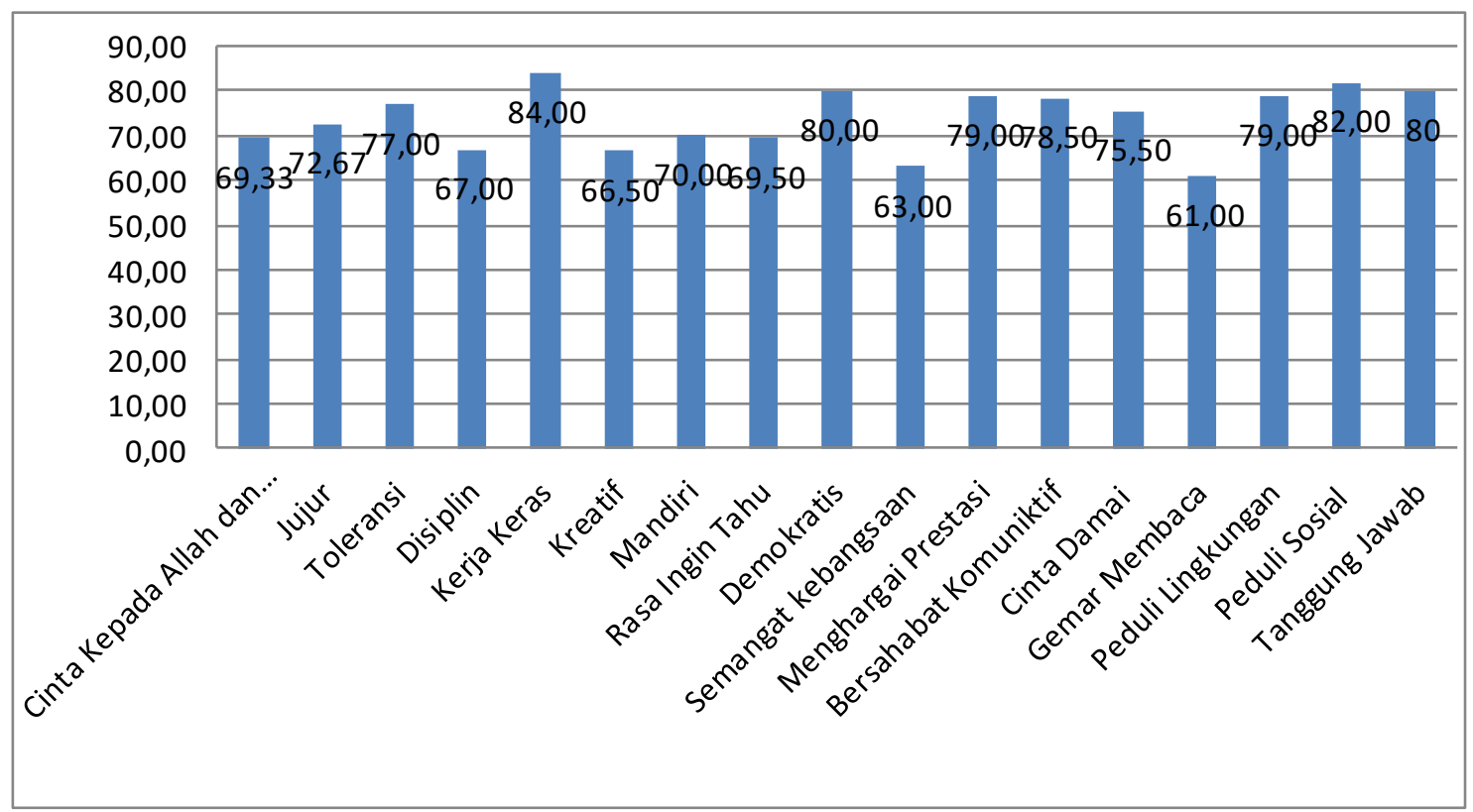

Grafik 1.2 memperlihatkan rata-rata persentase karakter yang ditampilkan mahasiswa di kelas per indikator. Karakter paling tinggi yakni kerja keras (84\%) dan yang paling rendah adalah gemar membaca (61\%).

Penelitian ini berusaha menjawab pertanyaan penelitian yakni "Bagaimanakah karakter yang ditampilkan mahasiswa melalui kegiatan islamisasi kampus di Universitas Muhammadiyah Sukabumi?.”. Dengan menggunakan instrumen lembar observasi diperoleh hasil mengenai gambaran karakter mahasiswa.

Universitas Muhammadiyah Sukabumi pengembangan atmosfir dan spirit AlIslam dan Kemuhammadiyahan (AIK) secara bertahap dan sistematis terus dilakukan. Di UMMI terdapat Lembaga Al-Islam dan Kemuhammadiyahan (AIK) yang menjadi pusat kegiatan AIK. Bagi mahasiswa selama ini telah dilaksanakan kuliah Al-Islam dan Kemuhammadiyahan selama 4 smt (total 8 SKS). UMMI juga telah menerapkan pembiasaan rutinitas Al-Islam dan Kemuhammadiyahan di kelas maupun luar kelas yang sesuai dengan SK Rektor No. 784/KEP/1.0 /C/2014 yakni:

1. Pembinaan AIK berupa pengajian rutin di tingkat universitas atau fakultas, kegiatan ini dimaksudkan untuk lebih mengenal aqidah islam, berupa ceramah/kajian rutin yang terjadwal. 
2. Pembiasaan mengucap salam, mengucapkan Assalamualaikum Warahmatullahi Wabarakatuh memiliki arti "semoga kedamaian dilimpahkan kepadamu diiringi dengan rahmat dari Allah SWT dan juga barakallah dari Allah untukmu. Pelaksanaan dilakukan ketika bertemu dalam pertemuan formal maupun non formal, pertemuan antar individu maupun kelompok.

3. Membaca Al-Qur'an, pelaksanannya di awal perkuliahan yang bertujuan untuk memberikan motivasi dan penyemangat bagi pembacanya.

4. Kultum atau kuliah tujuh menit, pelaksanaannya dalam setiap pertemuan baik rapat rutin, rapat evaluasi, atau saat ada rapat dengan mengundang pihak eksternal, juga kegiatan pertemuan lainnya.

5. Wajib menggunakan pakaian muslim yang sesuai dengan syariat islam, menutup aurat untuk dosen wanita dan mahasiswi sesuai syariat islam, kerudung menutup dada, pakaian longgar tidak memperlihatkan lekuk tubuh, menggunakan kaus kaki.

6. Menjaga kebersihan dan ketertiban di lingkungan kampus, dalam pelaksanaannya di lingkungan UMMI jika melihat sampah berserakan tidak harus menungu sampai petugas kebersihan datang, tertib saat perkuliahan, tidak parkir di sembarang tempat.

7. Solat berjamaah tepat pada waktunya, dilaksanakan saat waktu sholat wajib sedang berada di kampus.

8. Tidak merokok di lingkungan UMMI, di kampus UMMI tidak boleh merokok di semua tempat baik di gedung perkuliahan maupun di luar gedung perkuliahan.

Selain pembiasaan rutinitas AIK, mahasiswa semester 1 diwajibkan untuk mengikuti kegiatan mentoring Baca Tulis Al-Qur'an setiap minggu selama satu tahun akademik yang berisi latihan membaca Al-Qur'an dalam hal fashahah, makhraj dan tajwid berdasarkan pengelompokkan dari penjaringan BTQ di awal memasuki UMMI. Sertifikat BTQ yang diperoleh menjadi syarat kegiatan KKN dan terutama ujian sidang sarjana.

Berdasarkan hasil penelitian pada Grafik 1.1 mengenai karakter yang dapat teramati di lingkungan kampus. Karakter paling tinggi yakni disiplin (93.3\%) dan yang paling rendah adalah semangat kebangsaan (60\%). Disiplin yang diamati pada pengamatan di kampus yakni mngenai kepatuhan terhadap larangan untuk tidak 
merokok dan parkir pada tempatnya. Larangan merokok sudah jelas dalam pembiasaan AIK di UMMI sesuai SK Rektor No. 784/KEP/1.0 /C/2014, dan Fatwa Majelis Tarjih dan Tajdid Pimpinan Pusat Muhammadiyah No. 6/SM/MTT/III/2010. Alasan dilarangnya merokok menurut Fatwa dari Majelis Tarjih dan Tajdid adalah karena beberapa hal yang dianggap kuat untuk memfatwakan haramnya rokok, dan yang paling kuat adalah yang terdapat pada Q. S. Al-A'raf (7:157) “... dan yang menghalalkan segala yang baik bagi mereka dan mengharamkan segala yang buruk bagi mereka...", serta perbuatan merokok mengandung unsur menjatuhkan diri ke dalam kebinasaan dan bahkan merupakan perbuatan bunuh diri secara perlahan yang dilarang sesuai Q.S. AlBaqarah (2:195) “... dan janganlah kamu jatuhkan (diri sendiri) ke dalam kebinasaan dengan tangan sendiri...”, dan An-Nisa (4:29) “..Dan janganlah kamu membunuh dirimu. Sungguh Allah Maha Penyayang kepadamu”.

Adapun yang sangat erat kaitannya dengan islamisasi kampus adalah indikator cinta Allah dan ciptaan-Nya dengan nilai karakter sebesar $82.2 \%$ (baik). Adapun poinpoin pada indikator ini yakni mengenai suasana kampus yang mendorong mahasiswa untuk sholat tepat waktu, islamisasi kampus membuat mahasiswa betah serta nyaman kuliah di UMMI, mahasiswi mendapatkan motivasi untuk menutup aurat secara syar'i. Sehingga dapayt dikatakan bahwa islamisasi kampus di sekitar kampus dinilai mampu merevitalisasi karakter mahasiswa dengan baik.

Berdasarkan hasil penelitian pada Grafik 1.2 karakter paling tinggi yang dapat teramati di lingkungan kelas yakni indikator kerja keras (84\%), hal yang teramati dari indikator ini adalah mahasiswa bersungguh-sungguh dalam mengikuti perkuliahan dan mengerjakan tugas. Adapun indikator kedua yang tinggi setelah kerja keras adalah peduli sosial ( $82 \%$, baik) dan tanggung jawab (80\%, baik). Adapun yang paling rendah adalah gemar membaca (61\%, cukup) dan semangat kebangsaan (63\%, cukup). Indikator Cinta kepada Allah dan ciptaan Nya sebesar $69 \%$ (cukup). Dalam pembiasaan rutinitas AIK di UMMI kegiatan membaca Al-Qur'an maupun kultum di awal perkuliahan sangat ditekankan namun kategori persentasenya hanya mencapai cukup.

Apabila dibandingkan dengan hasil observasi di lingkungan kampus yaitu pada Grafik 1.1 maka indikator Cinta kepada Allah dan ciptaan Nya di lingkungan kelas agak bertentangan. Jika di lingkungan kampus cenderung baik (82.2\%) namun di kelas hanya sekedar cukup (60\%). Temuan ini dikonfirmasi dengan hasil wawancara kepada 5 
(lima) orang dosen. Dosen-dosen yang diwawancarai menyatakan bahwa mereka sangat tertarik dan setuju dengan konsep islamisasi kampus, dan berusaha untuk menerapkan sesuai dengan pembiasaan AIK di UMMI. Namun ke-lima nya mengakui bahwa pemahaman islamisasi kampus (bagi yang bukan dosen AIK) masih kurang, terutama dalam menyisipkan nilai-nilai islami pada materi mata kuliah yang diajarkan. Dan hal ini menjadi pekerjaan rumah bagi UMMI untuk lebih banyak memberikan pembinaan kepada dosen-dosen untuk memiliki kemampuan yang lebih baik dalam hal mengintegrasikan atau sekedar menyisipkan nilai-nilai islami kepada mahasiswa melalui pembelajaran di kelas, karena di kelaslah mahasiswa menghabiskan banyak waktu untuk mencari ilmu.

Pembelajaran di kelas adalah upaya memperoleh ilmu, dan ketika seseorang sudah berilmu maka Allah akan meninggikan derajatnya. Sebagaimana disebutkan dalam Al-Qur'an surat Al-Mujadalah ayat 11 yang berbunyi:“Hai orang-orang beriman apabila dikatakan kepadamu "Berlapang-lapanglah dalam majlis". Maka lapangkanlah niscaya Allah akan memberikan kelapangan untukmu. Dan apabila dikatakan: "Berdirilah kamu”, maka berdirilah, niscaya Allah akan meninggikan orang-orang yang beriman diantaramu dan orang-orang yang diberi ilmu pengetahuan beberapa derajat dan Allah Maha Mengetahui apa yang kamu kerjakan".

Menurut Ainiyah, pendidikan yang berhubungan dengan karakter adalah pendidikan kepribadian atau dalam agama islam disebut akhlak. Dalam mengajarkannya tidak dapat diajarkan dalam bentuk pengetahuan saja namun perlu adanya pembiasaan dalam kehidupan sehari-hari (Ainiyah, 2013). Hal ini diperkuat oleh Sudrajat karakter yang baik diperoleh dari kebiasaan ( $h a b b i t$ ), yakni kerika seseorang melakukan tindakan dengan sepenuh hati, tulus, dengan penuh kejujuran karena didasarkan kekuatan kebiasaan (Sudrajat, 2011). Dan pada tahap selanjutnya bahwa ketika seseorang mencintai hal yang baik, maka dengan senang hati ia akan melakukan yang baik buat semata-mata karena kewajiban moral.

Tujuan Perguruan Tinggi Muhammadiyah (PTM) adalah melahirkan sarjana muslim, baik dalam pengertian kultural maupun professional. Muslim secara kultural berarti mengetahui bagaimana cara mempergunakan pengetahuan dan keahlian yang dimiliki untuk meningkatkan harkat kehidupannya baik secara spiritual, intelektual maupun material. Secara professional berarti dapat menggunakan pengetahuannya 
untuk kepentingan masyarakat (Zamroni, 1990). Lebih lanjut menurut Anshari salah satu konsep sarjana muslim dapat dikembangkan dari ciri: 1) Memiliki keyakinan akan kebenaran dan kesempurnaan Islam., 2) Keaktifan dalam mempelajari ilmu dengan menyadari asumsi-asumsinya, 3) Kesadaran dan kegiatan sebagai insan da'i., 4) Kecintaan terhadap bangsa dan tanah air, 5) Kecintaan terhadap profesi dan pekerjaan (Zamroni, 1990).

Temuan penelitian ini bagi UMMI adalah suatu penelitian pendahuluan bahwa untuk menumbuhkan karakter yang baik bagi mahasiswa diperlukan pendekatan yang komprehensif. Hal ini dijelaskan oleh bahwa implementasi pendidikan karakter dapat diintegrasikan ke dalam semua bidang studi, menggunakan metode dan strategi yang bervariasi yang sedapat mungkin mencakup penanaman keteladanan, fasilitasi nilai, dan pengembangan soft skill (antara lain berfikir kritis, kreatif, berkomunikasi efektif dan pemecahan masalah) (Kristiawan, 2015).

Pendidikan karakter sesungguhnya adalah pendidikan yang diajarkan Rasulullah SAW. Misi umat islam sebagaimana dipesankan dan diteladankan Rasul dalam membangun peradaban manusia, tdk lain menyempurnakan akhlak mulia (HR. Bukhari). Pendidikan Muhammadiyah diselenggarakan terutama sebagai sarana untuk mendidik akhlak, yaitu usaha untuk membina karakter peserta didik yang baik menurut al-Qur'an dan Sunnah (Tohirin, 2016). Begitupun cita-cita Universitas Muhammadiyah Sukabumi harus terus berjuang melalui berbagai usaha untuk membangun karakter lulusan yang berkarakter islami untuk mendukung keunggulan bangsa Indonesia.

\section{SIMPULAN DAN SARAN}

Berdasarkan hasil pelaksanaan kegiatan ini maka dapat disimpulkan hal-hal sebagai berikut: 1) Karakter paling tinggi yang teramati di lingkungan kampus yakni disiplin (93.3\%) dan yang paling rendah adalah semangat kebangsaan (60\%). 2) Karakter paling tinggi yang ditampilkan mahasiswa di kelas yakni kerja keras (84\%) dan yang paling rendah adalah gemar membaca (61\%). 3) Merevitalisasi karakter dengan mengikuti ajaran Rasulullah SAW, adalah pekerjaan sepanjang hayat terutama di lembaga pendidikan dalam hal ini Universitas Muhammadiyah Sukabumi. 


\section{DAFTAR PUSTAKA}

Ainiyah, N. (2013). Pembentukan Karakter melalui Pendidikan Agama Islam. Jurnal Al-Ulum, 13(1), 25-38.

Akhsania, K. N. (2018). Pendidikan Karakter Prososial di Era Milenial dengan Pendekatan Konseling Realitas. In Prosiding SNBK (Seminar Nasional Bimbingan Dan Konseling) (Vol. 2, pp. 228-233).

Amri, M. (2018). Islam dan Pendidikan Karakter dalam Framing Media Online. Ta'dib, $\operatorname{VII}(1), 85-100$.

Azizah, A., Muslihudin, \& Suteja. (2013). Orientasi Pendidikan Karakter pada Mata Pelajaran Pendidikan Agama Islam (PAI) di Sekolah Menengah Atas (SMA) dalam Kurikulum 2013 Perspektif Thomas Lickona. Jurnal Al Tarbawi Al Haditsah, 1(2), 1-13.

Dalimunthe, R. A. A. (2015). Strategi dan Implementasi Pelaksanaan Pendidikan Karakter Di SMP N 9 Yogyakarta. Jurnal Pendidikan Karakter, V(1), 102-111.

Emmanuel, D. P. (2015). Rezim Pertumbuhan Kota Surabaya Studi tentang Pembangunan dan Revitalisasi Hotel di Surabaya. Jurnal Politik Muda, 4(1), $71-78$.

Hamid, A., \& Sudira, P. (2013). Penanaman Nilai-Nilai Karakter Siswa SMK Salafiyah Program Keahlian Teknik Komputer dan Jaringan (TKJ) Kajen, Margoyoso, Pati, Jawa Tengah. Jurnal Pendidikan Vokasi, 2(3), 1-15.

Hanrahmawan, F. (2010). Revitalisasi Manajemen Pelatihan Tenaga Kerja (Studi Kasus pada Balai Latihan Kerja Industri Makassar). Jurnal Administrasi Publik, 1(1), 78-94.

Hasyim, M. (2015). Konsep Pendidikan Karakter Perspektif Umar Baradja dan Relevansinya dengan Pendidikan Nasional. Cendekia: Jurnal Studi Keislaman, l(2), 151-169.

Iriany, I. S. (2014). Pendidikan Karakter sebagai Upaya Revitalisasi Jati Diri Bangsa. Jurnal Pendidikan Universitas Garut, 8(1), 54-85.

Johansyah. (2011). Pendidikan Karakter dalam Islam; Kajian dari Aspek Metodologis. Jurnal Ilmiah: Islam Futura, XI(1), 85-103.

Juanda. (2018). Revitalisasi Nilai dalam Dongeng sebagai Wahana Pembentukan Karakter Anak Usia Dini. Jurnal Pustaka Budaya, 5(2), 11-18.

Judiani, S. (2010). Implementasi Pendidikan Karakter di Sekolah Dasar melalui Penguatan Pelaksanaan Kurikulum. Jurnal Pendidikan Dan Kebudayaan, 16(9), 280-289.

Kristiawan, M. (2015). Telaah Revolusi Mental dan Pendidikan Karakter dalam Pembentukkan Sumber Daya Manusia Indonesia yang Pandai dan Berakhlak Mulia. Ta'dib, 18(1), 13-25. 
Kunaepi, A. (2013). Revitalisasi Pendidikan Karakter melalui Internaliasai PAI dan Budaya Religius. Jurnal At-Toqaddum, 5(2), 352-372.

Lalo, K. (2018). Menciptakan Generasi Milenial Berkarakter dengan Pendidikan Karakter Guna Menyongsong Era Globalisasi. Jurnal Ilmu Kepolisian, 12(2), $68-75$.

Majid, A., \& Andayani, D. (2012). Pendidikan Karakter Perspektif Islam. Bandung: Remaja Rosdakarya.

Munif, M. (2018). Pendidikan Karakter dalam Bahan Ajar Bahasa Arab Kelas 3 Madrasah Ibtida'iyah Kurikukulum 2013. Islamic Review: Jurnal Riset dan Kajian Keislaman, VII(2), 137-157.

Musanna, A. (2010). Revitalisasi Kurikulum Muatan Lokal untuk Pendidikan Karakter Melalui Evaluasi Responsif. Jurnal Pendidikan Dan Kebudayaan, 16(9), 245255.

Muslich, A. (2018). Nilai-Nilai Filosofis Masyarakat Jawa dalam Konteks Pendidikan Karakter di Era Milenial. Al-Asasiyya: Journal Basic Of Education, 2(2), 65-78.

Natasha, H. (2012). Revitalisasi Lembaga Pendidikan dalam Upaya Membangun Karakter Bangsa. Jurnal Pemikiran Islam, 37(1), 89-94.

Sakdiyah, H. (2010). Revitalisasi Entreprenuership di Pondok Pesantren Halimatus. AlIhkâ, V(2), 275-290.

Shobahiya, M., \& Suseno, A. (2013). Konsep Pendidikan Karakter Berbasis Potensi Diri dalam Film the Miracle Worker. Suhuf, 25(1), 76-99.

Sitorus, M. (2008). Kinerja dan Revitalisasi Birokrasi Publik. Jurnal Administrasi Publik, 5(1), 99-100.

Sudrajat, A. (2011). Mengapa Pendidikan Karakter? Jurnal Pendidikan Karakter, 1(1), $47-58$.

Sulianti, A. (2018). Revitalisasi Pendidikan Pancasila dalam Pembentukan Life Skill. Citizenship Jurnal Pancasila dan Kewarganegaraan, 6(2), 111-117.

Tohirin. (2016). Konsep dan Implementasi Pendidikan Karakter di Universitas Muhammadiyah Prof. Dr. Hamka Jakarta. Jurnal Penelitian Pendidikan Agama dan Keagamaan : Edukasi, 14(2), 279-314.

Wahono, M. (2018). Pendidikan Karakter: Suatu Kebutuhan Bagi Mahasiswa di Era Milenial. Integralistik, XXIX(2), 1-8.

Yuliana, E. D. (2012). Pentingnya Pendidikan Karakter Bangsa Merevitalisasi Ketahanan Bangsa. Jurnal Udayana Mengabdi, 9(2), 92-100.

Zamroni. (1990). Tantangan PTM dalam Mempersiapkan Sarjana Muslim: Suatu Tinjauan Kurikuler. Tulisan pada Tim AIK UMM. Muhammadiyah Sejarah, Pemikiran, dan Amal Usaha. Malang: Pusat Dokumentasi dan Publikasi UM 
Malang.

Zuchdi, D. (2010). Pengembangan Model Pendidikan Karakter Terintegrasi dalam Pembelajaran Bidang Studi di Sekolah Dasar. Cakeawala Pendidikan, 1(3), 112.

Zulhijrah. (2015). Implementasi Pendidikan Karakter Di Sekolah. Tadrib, 1(1), 1-19. 